\title{
PERFORMANCE AND EMISSION CHARACTERISTICS OF A CI ENGINE OPERATED ON VEGETABLE OILS AS ALTERNATIVE FUELS
}

\author{
K. Kalyani Radha ${ }^{1}$, S. Naga Sarada ${ }^{1}$, K. Rajagopal ${ }^{1}$ and E.L. Nagesh ${ }^{2}$ \\ ${ }^{1}$ Faculty of Mechanical Engineering \\ JNTUH College of Engineering, Kukatpally \\ Hyderabad-500085, Andhra Pradesh, India \\ Phone: +91 9440517729 \\ E-mail: kalyaniradha@gmail.com \\ ${ }^{2}$ Netaji Institute of Technology, Toopranpet \\ Nalgonda Dist, Andhra Pradesh, India
}

\begin{abstract}
An experimental analysis was done using a four-stroke, single cylinder, constant speed, water-cooled diesel engine, which was interfaced with Engine software. Performance and emission characteristics were evaluated for three non-edible vegetable oils, i.e. thumba, jojoba, neem oil, as well as jojoba methyl ester, to study the effect of injection pressure at 205, 220, 240 and 260 bar with a variation in injection timing at $23^{\circ} \mathrm{bTDC}$ and $28^{\circ} \mathrm{bTDC}$. The performance of jojoba methyl ester improved with an increase in injection pressure. A maximum brake thermal efficiency of $29.72 \%$ was obtained with lower emissions compared to the other vegetable oils; this might be explained by low viscosity and better combustion. Further investigations were carried out with a new lubricant, SAE 5W-30, which improved the performance of the CI engine by $1.59 \%$. All of the abovementioned investigations were fruitful and these results are expected to lead to substantial contributions in the development of a viable vegetable oil engine.
\end{abstract}

Keywords: alternative fuels; injection pressure; performance; lubricants; vegetable oils.

\section{INTRODUCTION}

The world is presently confronted with the twin crises of fossil fuel depletion and environmental degradation. Indiscriminate extraction and lavish consumption of fossil fuels have led to a reduction in underground-based carbon resources. The search for alternative fuels, which promise a harmonious correlation with sustainable development, energy conservation efficiency and environmental preservation, has become highly pronounced in the present context. Fuels of bio-origin can provide a feasible solution to this worldwide petroleum crisis. Gasoline and diesel-driven automobiles are the major sources of greenhouse gas (GHG) emissions. Scientists around the world have explored several alternative energy resources, which have the potential to quench the ever-increasing energy thirst of today's population. Various biofuel energy resources explored include biomass, biogas, primary alcohols, vegetable oils, biodiesel, etc. (Narayan, 2002; Ramadhas et al., 2002). These alternative energy resources are largely environmentally-friendly, but they need to be evaluated on a caseby-case basis in terms of their advantages, disadvantages and specific applications. Some of these fuels can be used directly while others need to be formulated to bring the relevant properties closer to conventional fuels. Due to the recent widespread use of 
petroleum fuels in various sectors, this study concentrated on assessing the viability of using alternative fuels in existing internal combustion engines.

The present energy scenario has stimulated active research interest in nonpetroleum, renewable and non-polluting fuels. The world reserves of primary energy and raw materials are obviously limited. The enormous growth of the global population, increased technical development and standards of living in industrial nations has led to this intricate situation in the field of energy supply and demand. The prices of crude oil keep rising and fluctuating on a daily basis. This necessitates developing and commercialising bio-origin fossil fuel alternatives. This may well be the main reason behind the growing awareness of and interest in unconventional bio-energy sources and fuels in various developing countries which are striving to offset the oil monopoly. There have been many attempts to use vegetable oils in diesel engines. Many researchers have reported encouraging engine performance with short-term usage, but have faced degraded engine performance after prolonged operation with vegetable oils. The reported problems include fuel filter clogging, deposit build-up in the combustion chamber, injector coking, piston ring sticking and lubrication oil thickening, all of which necessitate overhauling the engine and changing some parts (Lin et al., 2006; Khan et al., 2006; Altan et al., 2001; Kumar Reddy, 2000). The cumulative operation hours before overhaul is needed are shorter for vegetable oils than for diesel. One major obstacle in using vegetable oils is their high viscosity, which causes clogging of fuel lines, filters and injectors. In order to reduce the viscosity of vegetable oils, three methods have been found to be effective: transesterification, mixing with a lighter oil (blending) and pre-heating.

From the available literature, the use of vegetable oils in diesel engines has been associated with engine seizure, stickiness and carbon deposit problems. Noise, cold start and odour are other problems associated with these fuels. Due to their higher molecular weights, vegetable oils have low volatility and because of their unsaturation, they are inherently more reactive than diesel fuels (Ghormade, 2002; Ravi Kumar, 2007; Kumar Reddy, 2000). Although efforts are being made to use vegetable oils in engines, there is a need to optimise many design parameters of an engine operating under different conditions. For this purpose, a number of experimental investigations on different engines under different conditions must be carried out to arrive at useful general conclusions in order to develop a viable vegetable oil automotive engine. Keeping this in mind, the present study was designed. Injection pressures and injection timing were the parameters focused on in this study, where attention has not been paid by previous investigations. The scope of the present work was to examine the suitability of these oils as alternative fuels in a diesel engine, by evaluating their performance and emission characteristics with minor engine modifications and using new lubricants.

\section{EXPERIMENTAL SETUP}

A four-stroke, single cylinder, direct injection, water-cooled, computerised Kirloskar TV1 diesel engine was used for testing fuel performance with minor modifications. This engine can withstand the peak pressures encountered because of its original high compression ratio. Hence, this engine was selected for the present research. Table 1 shows the engine's specifications. 
Table 1. Engine specifications.

\begin{tabular}{ll}
\hline \multicolumn{1}{c}{ Engine } & $\begin{array}{l}\text { Four-stroke, single cylinder, constant } \\
\text { speed, water-cooled diesel engine }\end{array}$ \\
\hline BHP & 7 BHP @ 1500 RPM \\
Bore x Stroke & $87.5 \times 110 \mathrm{~mm}$ \\
Compression Ratio & $17.5: 1$ \\
Stroke & $110 \mathrm{~mm}$ \\
Bore & $87.5 \mathrm{~mm}$ \\
Dynamometer & Eddy current \\
\hline
\end{tabular}

Eddy Current Dynamometer: This consisted of a stator on which were fitted a number of electromagnets and a rotor disc coupled to the output shaft of the engine. When the rotor rotates, eddy currents are produced in the stator due to magnetic flux set up by the passage of a field current through the electromagnets. These eddy currents oppose the rotor motion, thus loading the engine. These eddy currents are dissipated by producing heat, so this type of dynamometer needs a cooling arrangement. A moment arm measures the torque. Regulating the current in the electromagnets controls the load.

Fuel Injection Pump: The fuel injection pump element was made by MICO BOSCH, with a plunger operated by the cam shaft.

Injection Pressure Measurement: Shims were used for changing the start of injection. This device can change the fuel injection timing from $23^{\circ}$ to $28^{\circ} \mathrm{bTDC}$, and was employed with a cam-type mechanism in the injection pump rocker arm. The fuel injection pump rocker arm, which oscillates between the fuel injection timing cam in the cam shaft and fuel injection pump plunger, is hinged on a cylindrical shaft at its centre. The cylindrical shaft was replaced by an eccentric shaft connected to a worm wheel gear assembly with a reduction ratio of 30:1. This advances the start of fuel injection timing.

Data Acquisition System: For studying the processes inside the cylinder, a data acquisition system was used. This was used for analysing the measured cylinder pressure data and to quantify the combustion parameters with variations in the crank angle. The components of the system are the pressure pick-up, charge amplifier, TDC position sensor, A/D card and a personal computer.

Smoke Meter: An AVL 437 C smoke meter measured the opacity of polluted air, in particular diesel exhaust gases. Opacity is defined as the extinction of light between the light source and the receiver. The gas to be measured is fed into a chamber with nonreflective inner surfaces. The effective length of the light absorption track was determined by taking into account the possible influence of devices used to protect the light source and the photocell. The effective length was $0.430 \pm 0.0005 \mathrm{~m}$. Light scatter on the photocell from reflections or diffused light inside the chamber was reduced to a minimum by the use of matt black light traps. The light source was an incandescent bulb with a temperature between $2800^{\circ} \mathrm{K}$ to $3250^{\circ} \mathrm{K}$. The response time of the electrical circuit, specified as the time within which the indicator reaches $90 \%$ of the full scale 
when a completely opaque plate is placed in front of the photocell, was between 0.9 and 1.1 seconds.

Exhaust Gas Analyser: A 5G-10 five-gas analyser (Planet Equipment, USA) was used to measure $\mathrm{HC}, \mathrm{CO}, \mathrm{CO}_{2}, \mathrm{O}_{2}$ and $\mathrm{NO}_{\mathrm{X}}$ emissions. Non-dispersive infrared measurements were used for $\mathrm{HC}, \mathrm{CO}$ and $\mathrm{CO}_{2}$ emissions, while for $\mathrm{NO}_{\mathrm{X}}$ and $\mathrm{O}_{2}$, electrochemical measurements were made by the exhaust analyser. The probe was inserted into the tailpipe of the engine and performed direct sensor measurements through the filter arrangement. The readings were displayed on the screen and saved. Cold traps were provided to prevent moisture from entering the exhaust gas analyser. The emission measurements were carried out on a dry basis.

\section{EXPERIMENTAL PROCEDURE}

All the variable load tests $(0,20 \%, 40 \%, 60 \%, 80 \%$ and $100 \%$ load) were conducted at a rated speed of $1500 \mathrm{rpm}$, but due to space limitations, the results are discussed only at full load. Injection timing and fuel injection pressures were the parameters which varied during the course of the experiment. The inlet temperature of the cooling water was maintained at $30^{\circ} \mathrm{C}$ and the outlet temperature at $70^{\circ} \mathrm{C}$. For all experiments, the lubrication oil temperature was maintained at $60^{\circ} \mathrm{C}$. The load on the dynamometer, air flow rate, fuel flow rate, exhaust temperature, manifold pressure, cooling water flow rate, cylinder head and cylinder liner temperatures, pressure time signal, TDC marker signal, dynamic injection timing, injection pressure, crank angle, $\mathrm{HC}, \mathrm{CO}, \mathrm{CO}_{2}, \mathrm{NO}_{\mathrm{X}}$ and smoke opacity readings were noted and recorded after allowing sufficient time (minimum of 15 to 20 minutes) for the engine to stabilise. The cylinder head temperatures were measured at two locations (i) near the exhaust valve and (ii) on the other side of the injector. Figure 1 shows the location of the thermocouples. Before the commencement of the experiment, the exhaust gas analyser was switched on. The data length and frequency range to trigger data acquisition for the computer were carefully selected based on the approximate cycle time of the engine operation, such that three TDC signals appeared on the display, with the combustion period occupying the centre stage. The ambient conditions of pressure and temperature were noted. The pressure and TDC signals were recorded and averaged over 100 consecutive cycles.

Experimentation: In the present investigation, the experiments were conducted in the test engine with minor engine modifications such as variations in load, variations in injection pressure and injection timing. Performance and emission characteristics were evaluated for three non-edible vegetable oils, including thumba oil, jojoba oil, neem oil and jojoba methyl ester with variations in the injection pressure at 205 bar, 220 bar, 240 bar and 260 bar at $23^{\circ} \mathrm{bTDC}$ and $28^{\circ} \mathrm{bTDC}$ fuel advancement (Radha, 2008). A comparison was made with the obtained results with diesel fuel as the control condition.

Conventional lubricants are not feasible with vegetable oil engines because of the high temperatures due to high frictional losses and lubricating oil dilution. Therefore, lubrication is one of the problems associated with these engines. Hence, in the last phase of this experiment, the vegetable oil-fuelled engine was tested with the specially developed lubricant SAE 5W-30 which reduces the clogging of nozzle tips, as discussed in the Results. Table 2 and Table 3 show the properties of the vegetable oils and lubricants. 


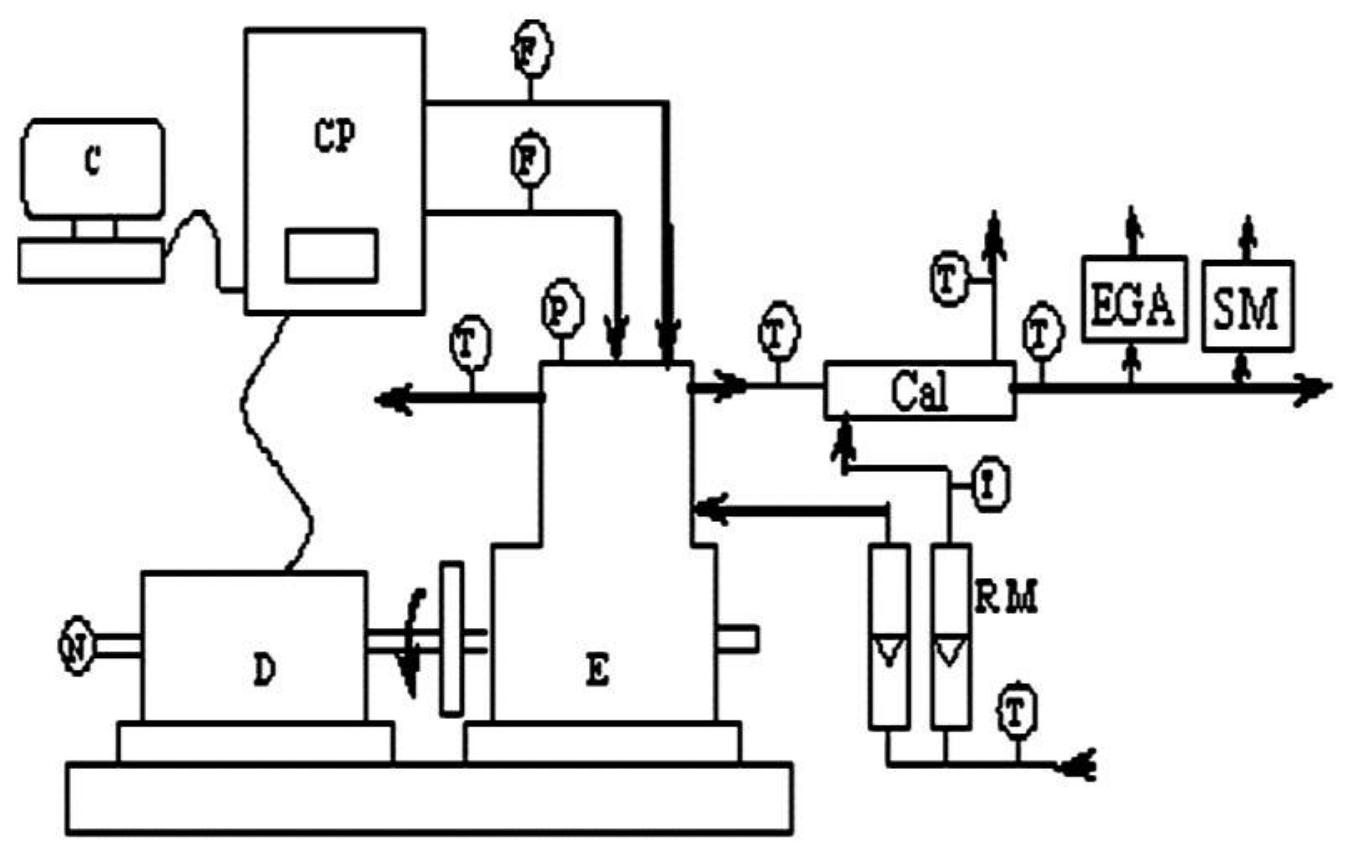

Figure 1. Experimental setup.

Table 2. Properties of the vegetable oils.

\begin{tabular}{lccccc}
\hline \multicolumn{1}{c}{$\begin{array}{c}\text { Property/ } \\
\text { Equipment }\end{array}$} & Diesel oil & Neem oil & $\begin{array}{c}\text { Thumba } \\
\text { oil }\end{array}$ & $\begin{array}{c}\text { Jojoba } \\
\text { oil }\end{array}$ & $\begin{array}{c}\text { Jojoba } \\
\text { methyl } \\
\text { ester }\end{array}$ \\
\hline Colour & Colourless & Brownish & $\begin{array}{c}\text { Light } \\
\text { yellow }\end{array}$ & $\begin{array}{c}\text { Golden } \\
\text { yellow }\end{array}$ & $\begin{array}{c}\text { Light } \\
\text { golden } \\
\text { yellow }\end{array}$ \\
$\begin{array}{l}\text { Density }\left(\mathrm{kg} / \mathrm{m}^{3}\right) \\
\left(\text { Hydrometer @ 25 }{ }^{\circ} \mathrm{C}\right)\end{array}$ & 840 & 919 & 919 & 866 & 846 \\
$\begin{array}{l}\text { Kinematic viscosity } \\
(\mathrm{cSt})\end{array}$ & 2.6 & 48 & 45 & 40 & 2.9 \\
$\begin{array}{l}\text { Redwood Viscometer } \\
\text { No.1 @ 40 } \mathrm{C} \text { ) } \\
\text { Calorific value(kJ/kg) } \\
\text { (Bomb calorimeter) }\end{array}$ & 42000 & 36000 & 38000 & 37575 & 39550 \\
\hline
\end{tabular}


Table 3: Properties of the lubricants

\begin{tabular}{|c|c|c|}
\hline Property/Method & SAE 40 & SAE 5W-30 \\
\hline $\begin{array}{l}\text { Specific Gravity } \\
\text { (ASTM D-1298) }\end{array}$ & 0.901 & 0.86 \\
\hline $\begin{array}{l}\text { Viscosity @ } 40^{\circ} \mathrm{C} \text {, Cst } \\
\text { (ASTM D-445) }\end{array}$ & 83.7 & $58-73$ \\
\hline $\begin{array}{l}\text { Viscosity Index } \\
\text { (ASTM D-2270) }\end{array}$ & 184 & 160 \\
\hline $\begin{array}{l}\text { Cold Cranking Viscosity } \\
\text { (ASTM D-5293) }\end{array}$ & 5691 & $6,000 @-30^{\circ} \mathrm{C}, \mathrm{cP}$ \\
\hline $\begin{array}{l}\text { Flash Point }{ }^{\circ} \mathrm{F} /{ }^{\circ} \mathrm{C} \\
\text { (ASTM D-92) }\end{array}$ & $439 / 226$ & $445 / 229.44$ \\
\hline $\begin{array}{l}\text { Stable Pour Point }{ }^{\circ} \mathrm{F} /{ }^{\circ} \mathrm{C} \\
\text { (FTM } 7916 \text { Method 203) }\end{array}$ & $<-61 /<-51$ & $<-41 /<-42$ \\
\hline $\begin{array}{l}\text { High Temperature/High Shear } \\
\text { Viscosity } 302^{\circ} \mathrm{F} /{ }^{\circ} \mathrm{C}, \mathrm{cP} \\
\text { (ASTM D- } 4683 \text { ) }\end{array}$ & 4.81 & 3.2 \\
\hline $\begin{array}{l}\text { Specific Gravity } \\
\text { (ASTM D-1298) }\end{array}$ & 0.901 & 0.86 \\
\hline $\begin{array}{l}\text { Viscosity @ 40 } \\
\text { (ASTM D- } 445 \text { ) }\end{array}$ & 83.7 & $58-73$ \\
\hline $\begin{array}{l}\text { Viscosity Index } \\
\text { (ASTM D-2270) }\end{array}$ & 184 & 160 \\
\hline $\begin{array}{l}\text { Cold Cranking Viscosity } \\
\text { (ASTM D-5293) }\end{array}$ & 5691 & $6,000 @-30^{\circ} \mathrm{C}, \mathrm{cP}$ \\
\hline $\begin{array}{l}\text { Flash Point }{ }^{\circ} \mathrm{F} /{ }^{\circ} \mathrm{C} \\
\text { (ASTM D-92) }\end{array}$ & $439 / 226$ & $445 / 229.44$ \\
\hline $\begin{array}{l}\text { Stable Pour Point }{ }^{\circ} \mathrm{F} /{ }^{\circ} \mathrm{C} \\
\text { (FTM } 7916 \text { Method } 203 \text { ) }\end{array}$ & $<-61 /<-51$ & $<-41 /<-42$ \\
\hline $\begin{array}{l}\text { High Temperature/High Shear } \\
\text { Viscosity } 302^{\circ} \mathrm{F} /{ }^{\circ} \mathrm{C}, \mathrm{cP} \\
\text { (ASTM D-4683) }\end{array}$ & 4.81 & 3.2 \\
\hline
\end{tabular}

\section{TRANSESTERIFICATION PROCESS}

In view of improving performance and reducing emissions, an attempt was made using the methyl ester of jojoba oil as a fuel. The performance and emission characteristics of jojoba methyl ester were compared to those of straight jojoba oil. This involved the process of converting the vegetable oil into biodiesel. In this analysis, jojoba methyl ester was obtained by treating jojoba oil with methanol (Huzayyin, et al., 2004; Naik et al., 2008; Radwan, et al., 2007; Srinivasa Murthy, 2005) in the presence of a base catalyst $(\mathrm{KOH})$. This was done by adding $4.5 \mathrm{~g}$ of $\mathrm{NaOH}$ to $200 \mathrm{ml}$ of methanol. This was mixed with 1 litre of jojoba oil in a glass container. The apparatus was placed on a magnetic stirrer with a hot plate to maintain a constant temperature $\left(65^{\circ} \mathrm{C}\right.$ for 90 minutes) throughout the mixture. The reaction took approximately one hour to complete and the mixture was kept undisturbed for about $9 \mathrm{~h}$ to settle. The products of the reaction included glycerine, a cloudy-looking product which settled at the bottom, and the methyl ester, a translucent liquid which remained on top, showing two-layer 
separation. The separation was caused by density variation and the ester was taken out by means of a separation funnel. Water was added to the separated ester which mixed with traces of glycerine to form soap, which settled at the bottom. This was then separated. Air was bubbled through the ester for about $10 \mathrm{~min}$. The resulting product was fully devoid of glycerine. The yield was $950 \mathrm{ml}$ of methyl ester, which resulted in a $95 \%$ conversion efficiency.

\section{RESULTS AND DISCUSSION}

The performance and emission characteristics were evaluated for three non-edible vegetable oils, including thumba oil, jojoba oil and neem oil with variations in the injection pressure at 205 bar, 220 bar, 240 bar and 260 bar and at $23^{\circ} \mathrm{bTDC}$ and $28^{\circ} \mathrm{bTDC}$ fuel advancement. Figure 2 shows the variation in brake thermal efficiency at different injection pressures at $23^{\circ} \mathrm{bTDC}$ and $28^{\circ} \mathrm{bTDC}$. It was observed that the maximum brake thermal efficiencies of $25.35 \%$ and $29.72 \%$ (at the full load condition) were obtained for JME at 220 bar injection pressure at $23^{\circ} \mathrm{bTDC}$ and $28^{\circ} \mathrm{bTDC}$, respectively. For JME, BTE improved by $9.78 \%$ as the injection pressure was increased from 205 bar to 220 bar at $23^{\circ} \mathrm{bTDC}$, and BTE improved by $15.4 \%$ at $28^{\circ} \mathrm{bTDC}$. The BTE of all vegetable oils at lower injection pressures were low due to coarse spray formation, poor atomisation and mixture formation. Beyond 220 bar, the reduction in BTE may have been because of ineffective combustion due to the increased depth of penetration. The BTE improved by $14.7 \%$ as the injection timing was increased from $23^{\circ} \mathrm{bTDC}$ to $28^{\circ} \mathrm{bTDC}$. With an increase in injection pressure and injection timing to 220 bar and $28^{\circ}$ bTDC, the BTE increased, which may have been due to the fine spray which formed during injection and improved atomisation with fuel advancement. As the injection timing advanced from $23^{\circ} \mathrm{bTDC}$ to $28^{\circ} \mathrm{bTDC}$, the BTE was found to improve due to better combustion. Hence, 220 bar and $28^{\circ}$ bTDC may be considered as the optimum injection pressure and injection timing for running the engine with JME because of the higher BTE.

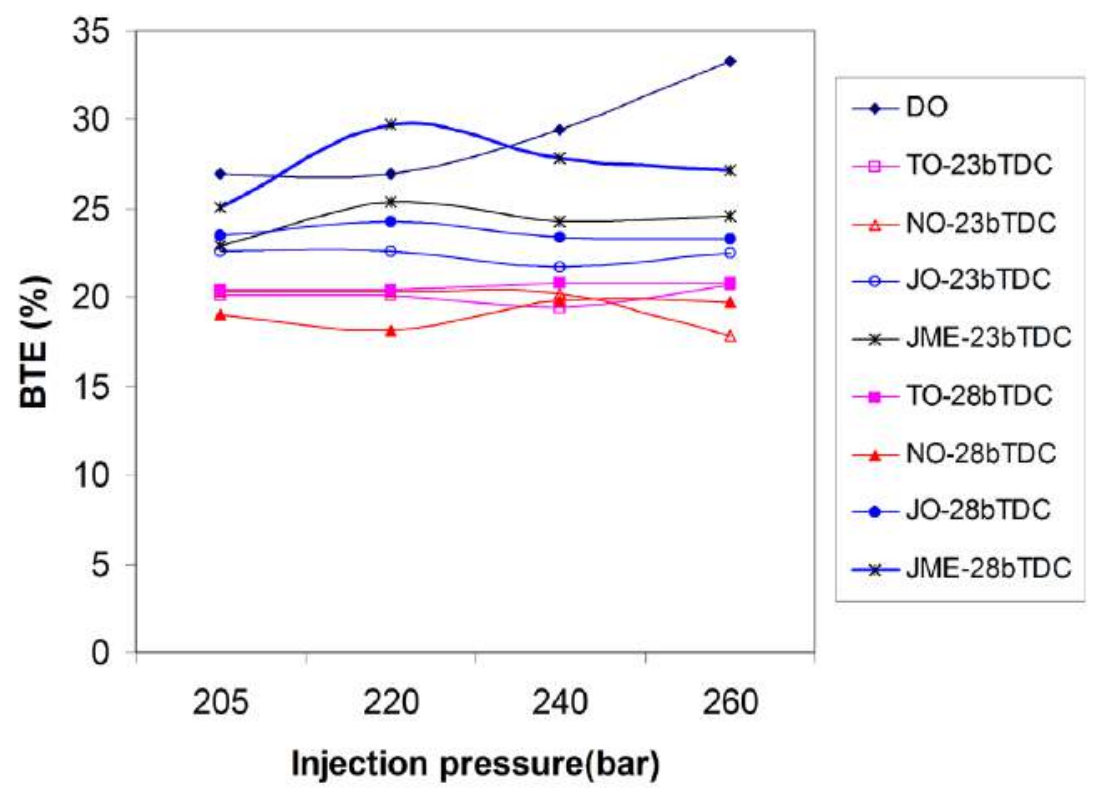

Figure 2. Variation in BTE with injection pressure at full load 
Figure 3 shows the variation in BSFC with different injection pressures at $23^{\circ} \mathrm{bTDC}$ and $28^{\circ} \mathrm{bTDC}$ at full load. It was observed that the BSFC decreased with an increase in injection pressure from 205 bar to 220 bar, and increased with higher injection pressures. The lowest BSFC values were found at 220 bar with $0.371 \mathrm{~kg} / \mathrm{kWh}$ and $0.3256 \mathrm{~kg} / \mathrm{kWh}$ at $23^{\circ} \mathrm{bTDC}$ and $28^{\circ} \mathrm{bTDC}$, respectively, but these values were greater than those for diesel. The BSFC reduced by $12.23 \%$ as the injection timing was increased from $23^{\circ} \mathrm{bTDC}$ and $28^{\circ} \mathrm{bTDC}$. At higher injection pressures, the reduction in BSFC may have occurred because the plunger in the fuel injection pump discharged a greater amount of fuel into the combustion chamber due to the higher densities of the vegetable oils compared to diesel.

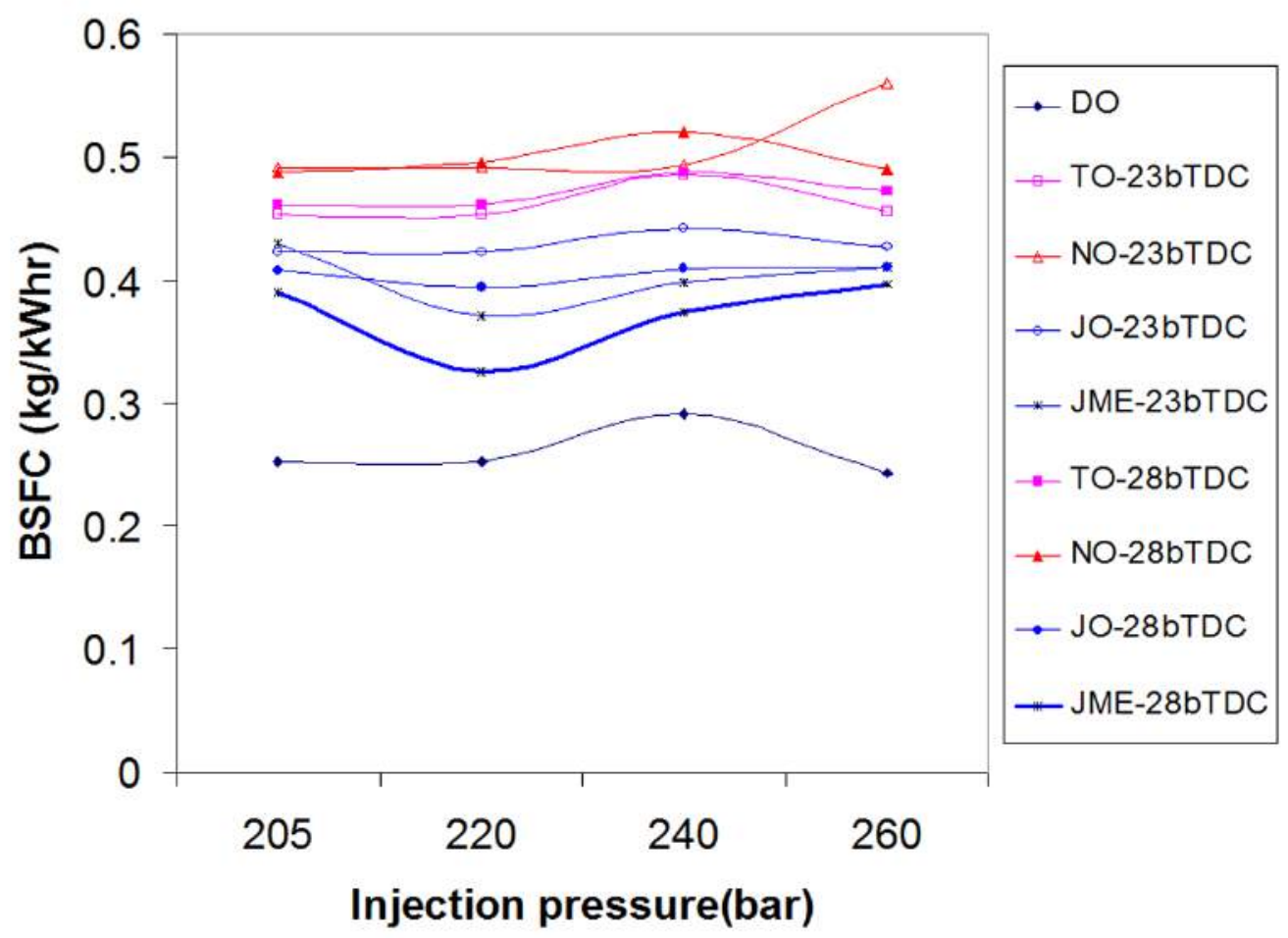

Figure 3. Variation in BSFC with injection pressure at full load

Figure 4 shows the variation in $\mathrm{HC}$ with varying injection pressures at $23^{\circ} \mathrm{bTDC}$ and $28^{\circ} \mathrm{bTDC}$ at full load. Unburnt hydrocarbons are the result of incomplete combustion of fuel. As the injection pressures increased, the $\mathrm{HC}$ emissions were reduced for the vegetable oils; the lowest amount was seen for JME at 220 bar. At higher pressures, there seemed to be an increase in HC emissions, which may have occurred because of the finer fuel spray which reduces the momentum of the droplets, resulting in less complete combustion. For jojoba methyl ester, the $\mathrm{HC}$ emissions were reduced by $14.8 \%$ as the fuel advanced from $23^{\circ} \mathrm{bTDC}$ to $28^{\circ} \mathrm{bTDC}$ and were found to be lower than with diesel. The maximum emissions were observed for thumba oil. 


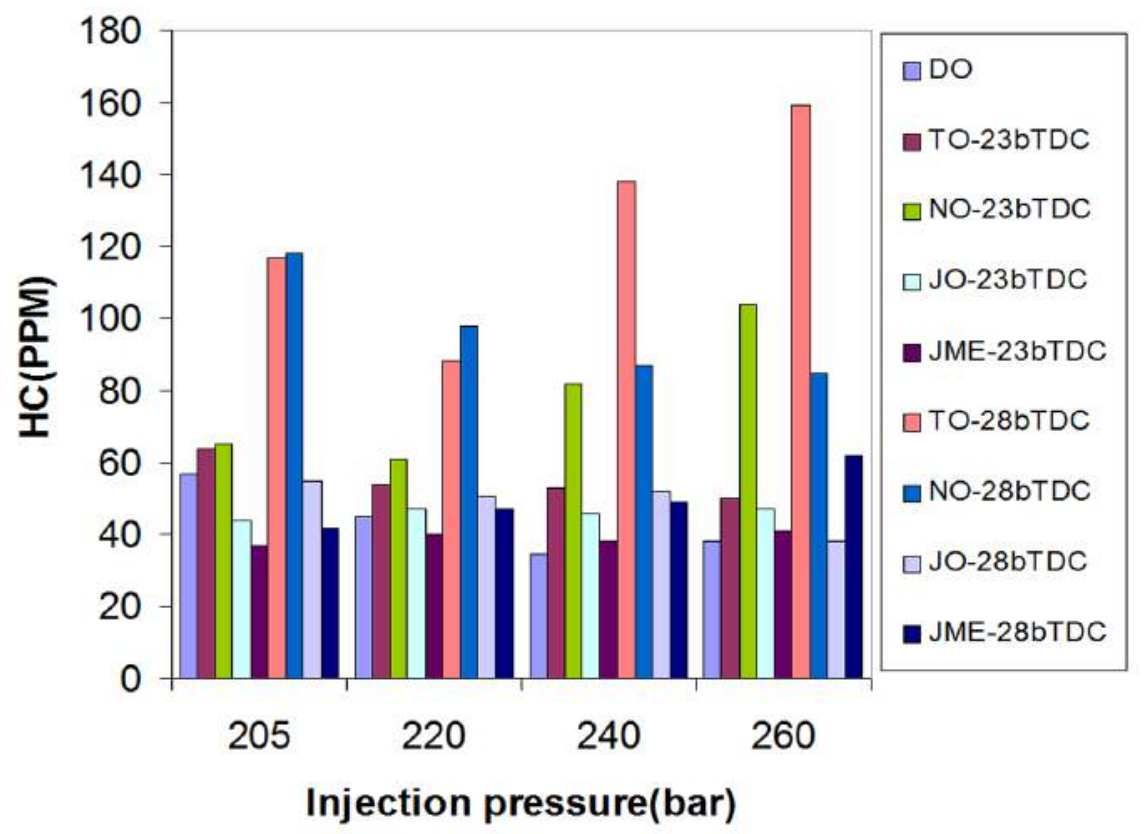

Figure 4. Variation in $\mathrm{HC}$ with injection pressure at full load.

Figure 5 shows the variation in $\mathrm{CO}$ with varying injection pressures at $23^{\circ} \mathrm{bTDC}$ and $28^{\circ} \mathrm{bTDC}$ at full load. CO emissions increased with increased injection pressures for all of the vegetable oils and were higher than with diesel. This may have been due to less effective combustion at these higher pressures. Minimum $\mathrm{CO}$ emissions were found for JME as compared to the other vegetable oils at 220 bar, with values of $1.12 \%$ at $23^{\circ} \mathrm{bTDC}$ and $1.19 \%$ at $28^{\circ} \mathrm{bTDC}$ at full load.

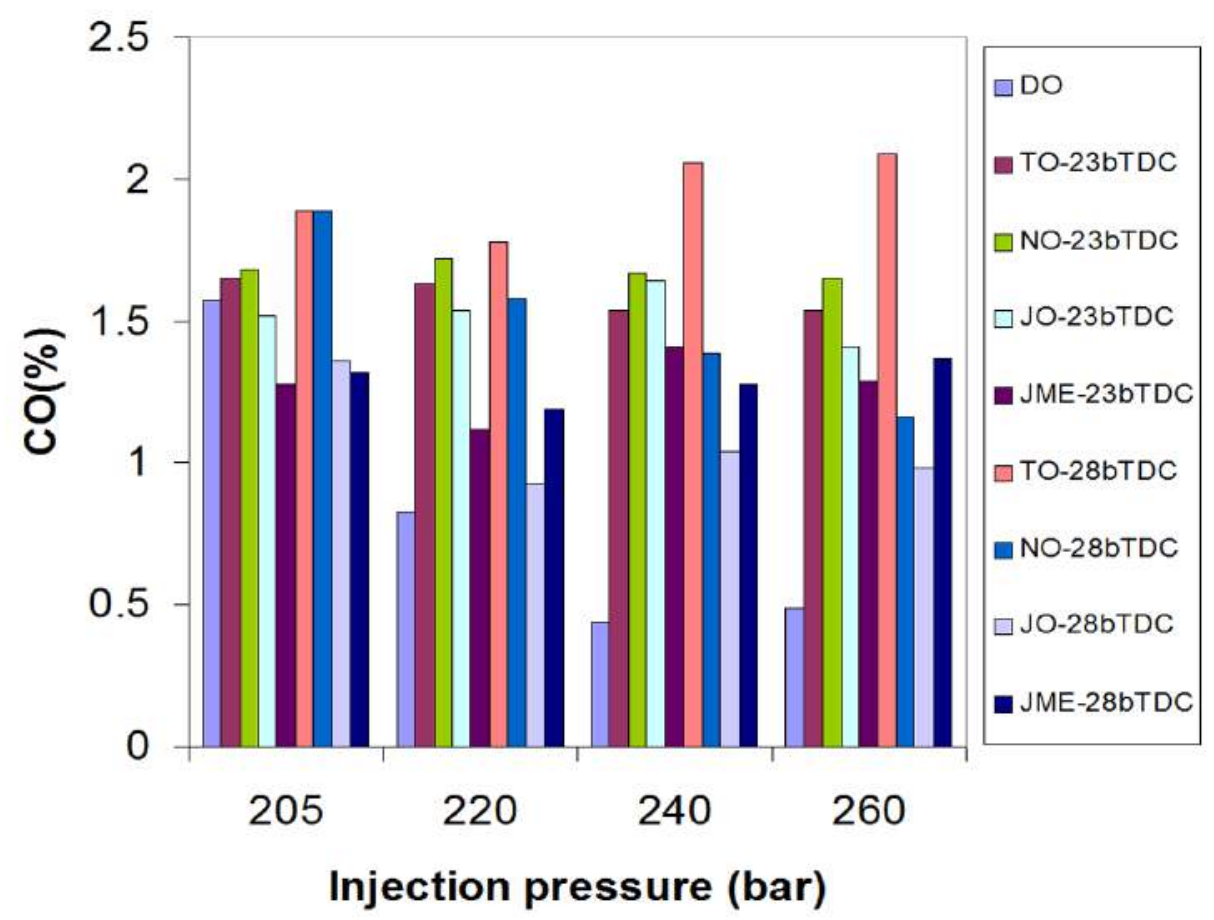

Figure 5. Variation in $\mathrm{CO}$ with injection pressure at full load. 
Figure 6 shows the variation in $\mathrm{CO}_{2}$ with different injection pressures at full load. $\mathrm{CO}_{2}$ emissions increased with increased injection pressures for all of the vegetable oils, but were lower than with diesel by $15.4 \%$ at 220 bar and $23^{\circ} \mathrm{bTDC}$. This may have been due to less effective combustion at these higher pressures. Lower $\mathrm{CO}_{2}$ emissions were found for JME compared to the other vegetable oils at all injection pressures. It was observed that as the injection timing advanced from $23^{\circ} \mathrm{bTDC}$ to $28^{\circ} \mathrm{bTDC}$, the $\mathrm{CO}_{2}$ emissions were reduced by $4.6 \%$ at 220 bar, which may have been due to the oxygen content in JME.

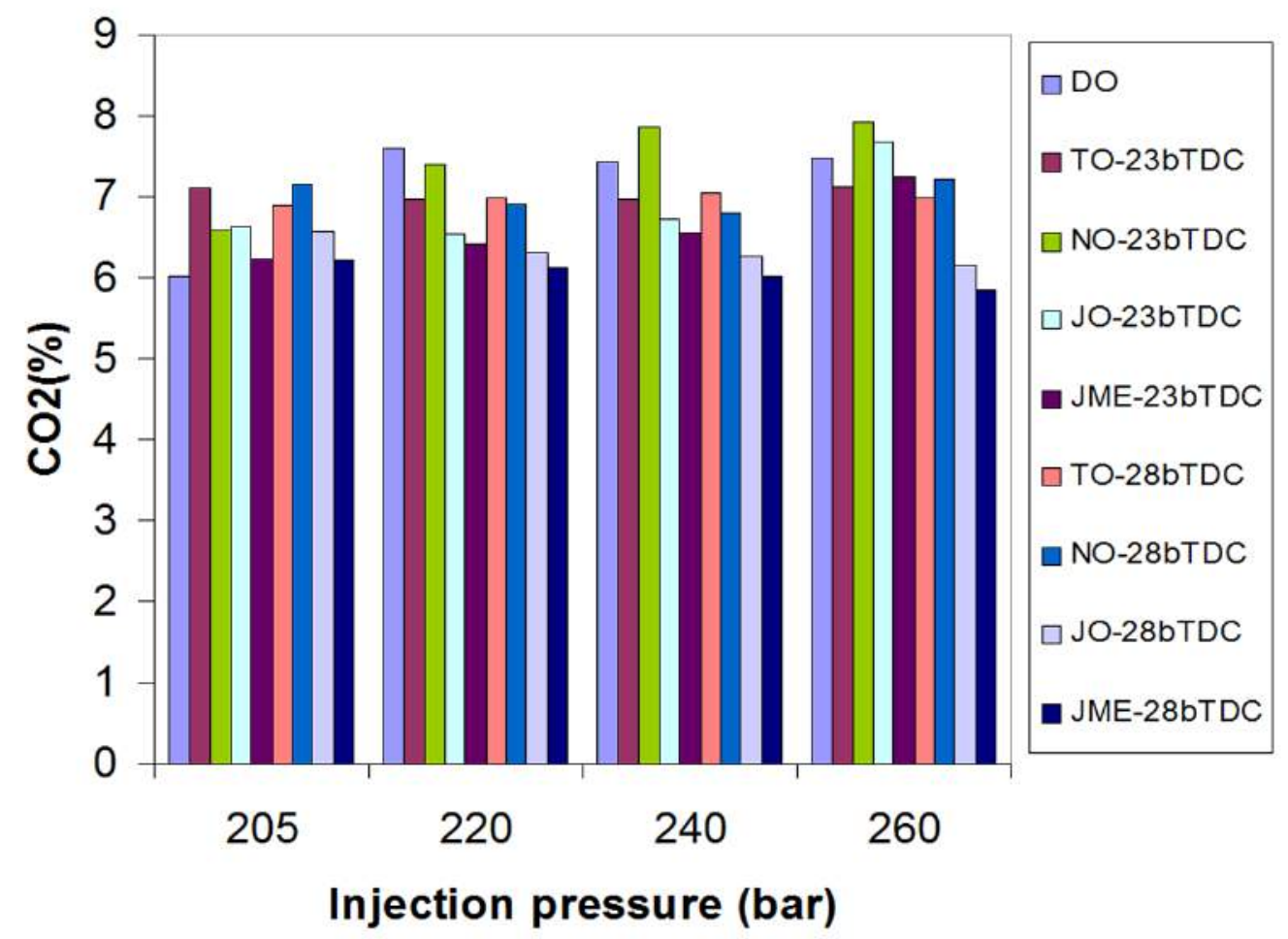

Figure 6. Variation in $\mathrm{CO}_{2}$ with injection pressure at full load

Figure 7 shows the variation in $\mathrm{NO}_{\mathrm{x}}$ emissions with different injection pressures at $23^{\circ} \mathrm{bTDC}$ and $28^{\circ} \mathrm{bTDC}$ at full load. $\mathrm{NO}_{\mathrm{x}}$ emissions increased with increased injection pressures and injection timing at all loads for JME, and were lower for the other vegetable oils. With JME, it was observed that at an injection pressure of 220 bar, the nitrogen oxide emissions at full load were comparable with those of diesel and were only marginally higher at $28^{\circ} \mathrm{bTDC}$. The higher emissions were due to higher exhaust temperatures.

Figure 8 shows the variation in smoke opacity with varying injection pressures. The highest smoke opacities were recorded for vegetable oils at all injection pressures. The smoke opacity for JME was comparable with diesel at 220 bar and $23^{\circ} \mathrm{bTDC}$ and was reduced by $10.22 \%$ as the injection timing advanced from $23^{\circ} \mathrm{bTDC}$ to $28^{\circ} \mathrm{bTDC}$ at 220 bar. The presence of oxygen in JME, in addition to good atomisation at higher pressures, may have been the reason for lower opacity. 


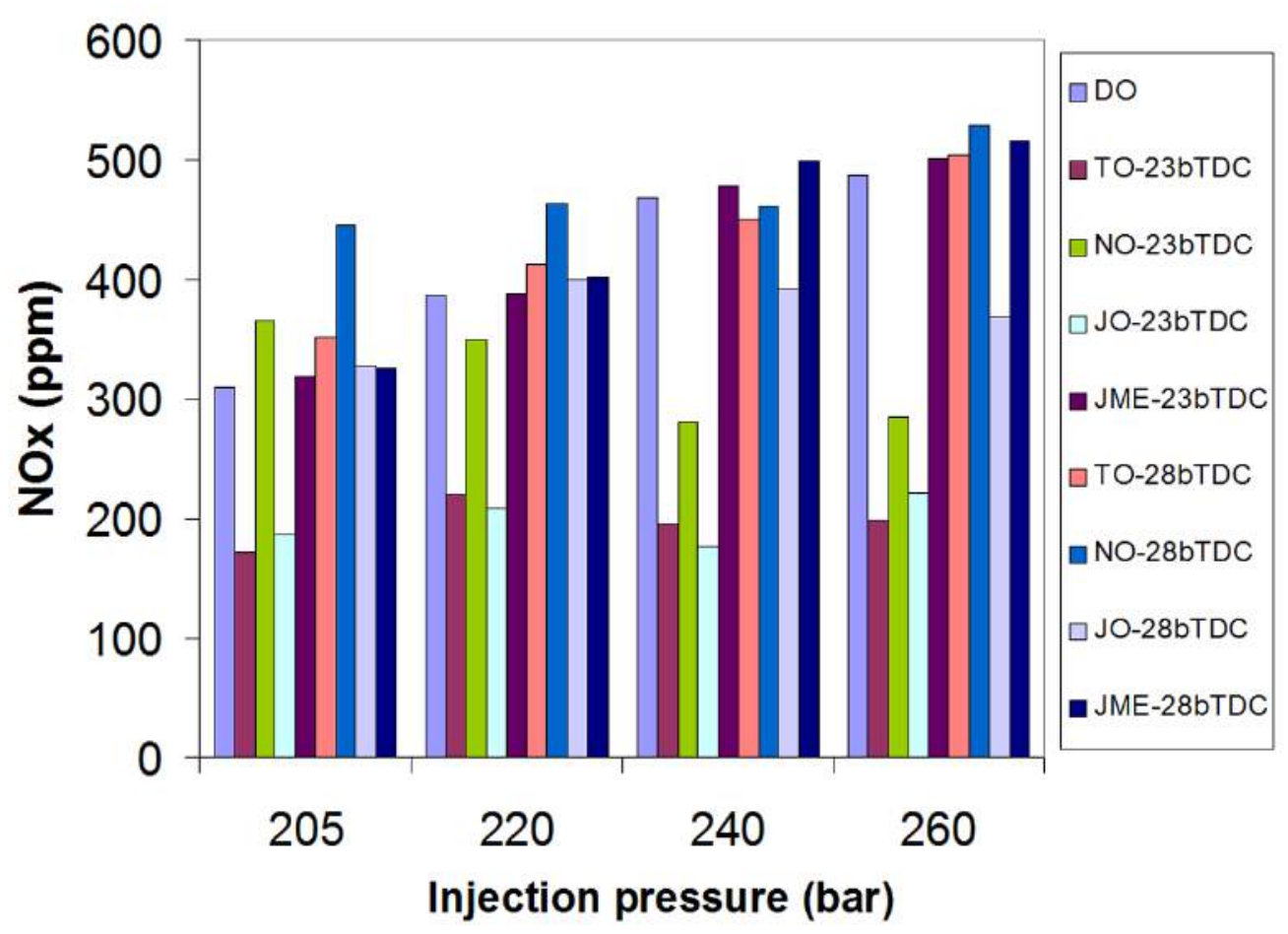

Figure 7: Variation in $\mathrm{NO}_{\mathrm{x}}$ with injection pressure at full load

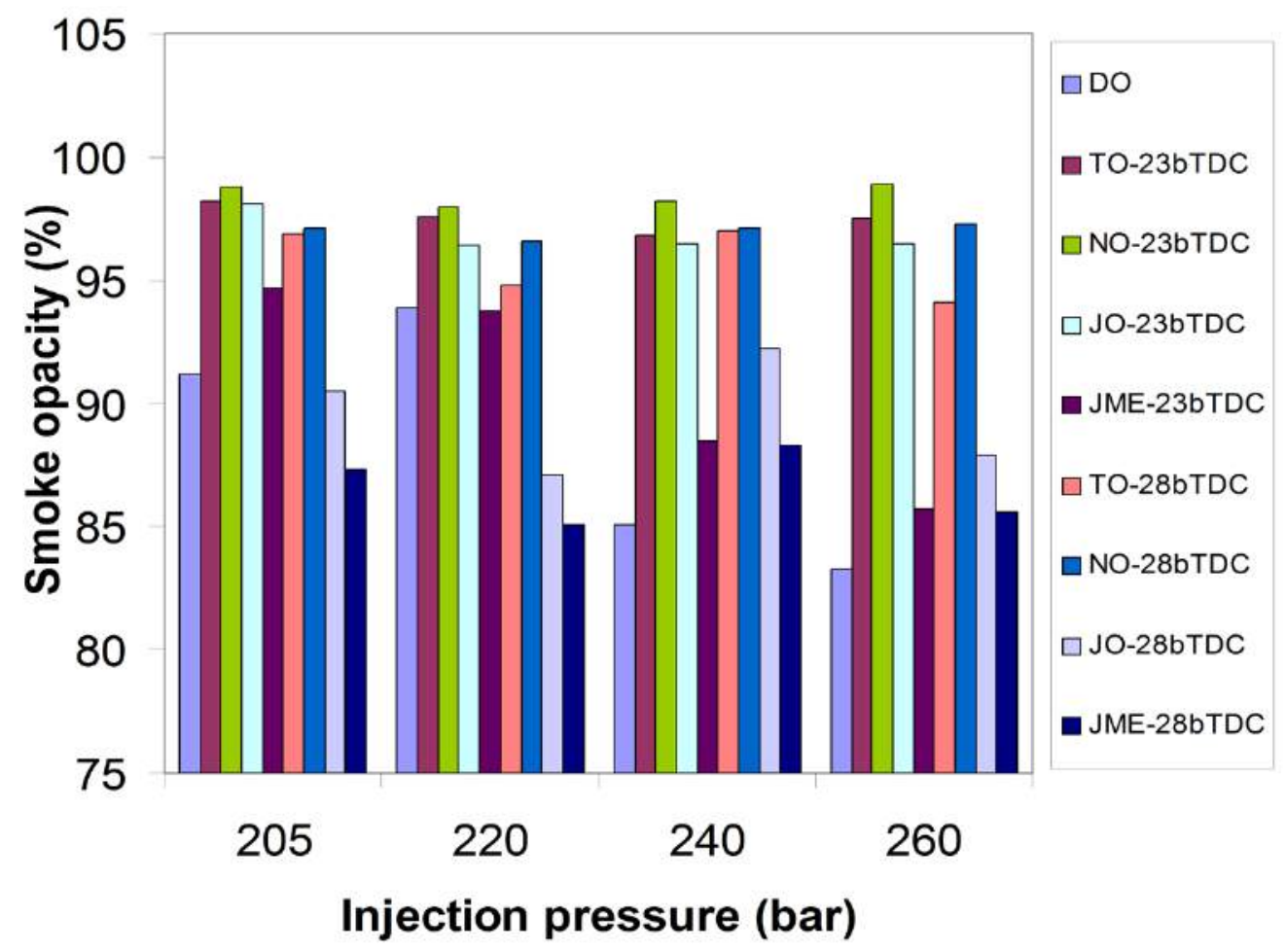

Figure 8. Variation in smoke opacity with injection pressure at full load.

Figure 9 shows the comparison of brake thermal efficiency at full load for the SAE 40 and SAE 5W-30 lubricants. It was observed that the BTE improved using SAE $5 \mathrm{~W}-30$ and also improved with an increase in injection pressure and injection timing from $23^{\circ} \mathrm{bTDC}$ to $28^{\circ} \mathrm{bTDC}$. For JME, BTE improved by $4.2 \%$ as the injection pressure 
increased from 205 bar to 220 bar at $23^{\circ}$ bTDC, and BTE improved by $8.6 \%$ at $28^{\circ} \mathrm{bTDC}$ compared to jojoba oil. This may have been due to a reduction in frictional losses, as nozzle clogging was not observed, possibly due to better atomisation of the fuel. The maximum BTE of $30.2 \%$ was observed for JME at 220 bar and $28^{\circ} \mathrm{bTDC}$ using SAE 5W-30 as the lubricant; this was $10.8 \%$ higher than that of diesel.

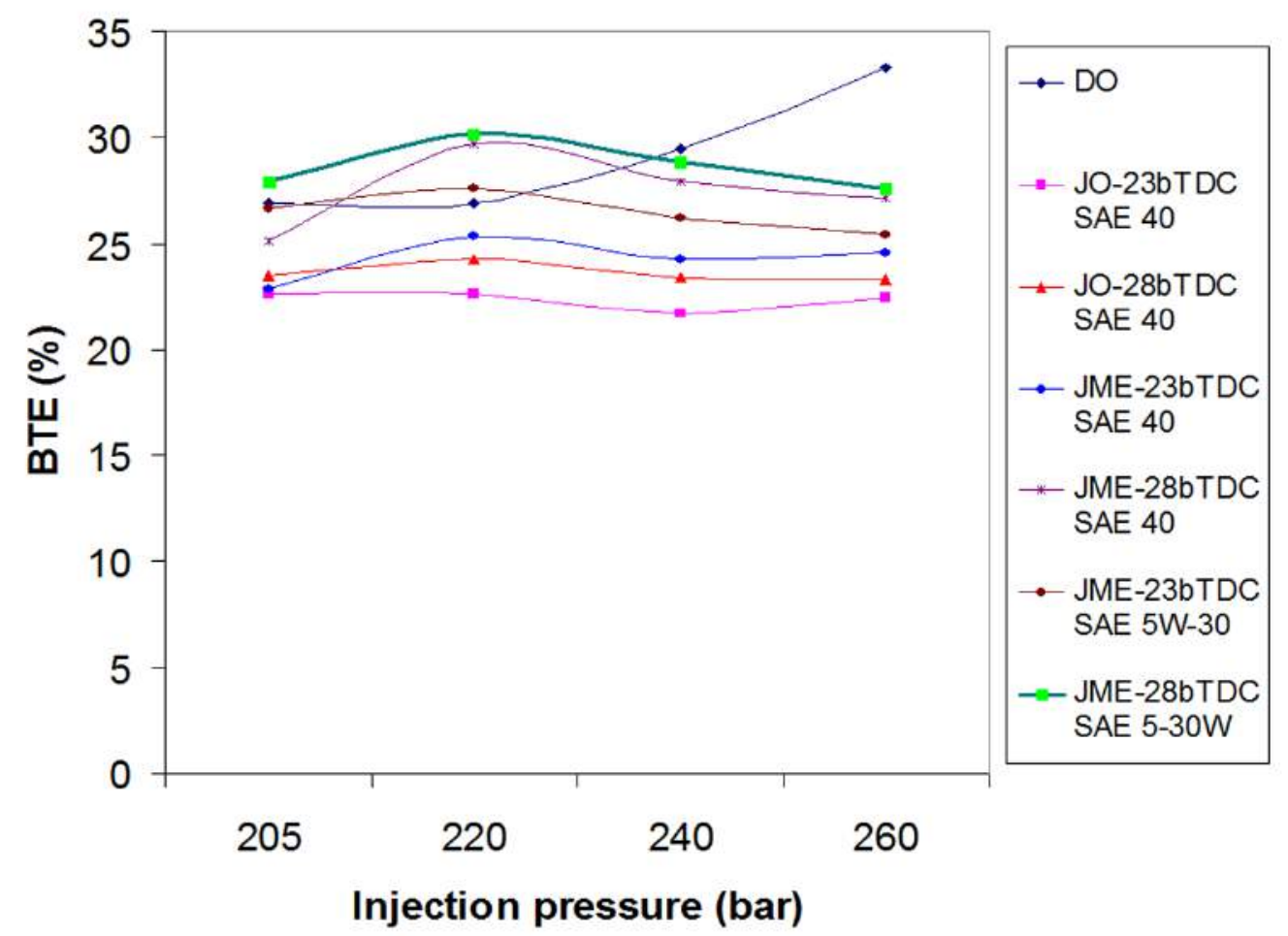

Figure 9. Variation in BTE with injection pressure at full load for SAE40 and SAE $5 \mathrm{~W}-30$.

\section{CONCLUSION}

Based on the experimental results of the present investigation, the following conclusions can be drawn. Among the different injection pressures and injection timings at 220 bar and $28^{\circ} \mathrm{bTDC}$ was found to be optimal for improved performance and lower exhaust emissions compared to diesel fuel and other vegetable oils. From the above results, JME can be used as an alternative fuel with better performance and lower emissions with $28^{\circ} \mathrm{bTDC}$ injection timing and 220 bar injection pressure in a direct injection diesel engine with minor modifications. Through the use of new lubricants, the brake thermal efficiency was improved, which might have been due to a reduction in frictional losses. The results suggest that these oils can be successfully used in automotive engines with minor modifications. It can be concluded from the experimental investigation that the development of efficient vegetable oil-fuelled engines is possible. Future work may be extended in the following directions:

- $1000 \mathrm{~h}$ durability tests should be conducted on diesel engines and the wear associated with engine moving parts should be analysed.

- Future studies on engines may include endurance testing to evaluate components, coatings and tribological durability. 
- Studies on future biodiesel and biodiesel-diesel blend fuels should be carried out in order to reduce the viscosity of non-edible vegetable oils.

- These investigations may be carried out in high speed automobile multi-cylinder engines for better combustion characteristics.

- Future low heat rejection, dual fuel, turbo-charged engine studies should be conducted with ceramic alloys that are currently being used but have the disadvantage of brittleness.

\section{ACKNOWLEDGEMENTS}

The authors wish to thank the Department of Mechanical Engineering, JNT University, Hyderabad for providing facilities (under TEQIP) to carry out this work.

\section{REFERENCES}

Altan, R., Cetinkay, S. and Yucesu, H.S. 2001. The potential of using vegetable oil fuels as fuel for diesel engines. Energy Conversion and Management, 42(5): 529-538.

Ghormade, T.K. and Deshpande, N.V. 2002. Soybean oil as an alternative fuels for I. C. engines. Proceedings of Recent Trends in Automotive Fuels, Nagpur, India.

Huzayyin, A.S., Bawady, A.H., Rady, M.A. and Dawood, A. 2004. Experimental evaluation of Diesel engine performance and emission using blends of jojoba oil and Diesel fuel. Energy Conversion and Management, 45: 2093-2112.

Khan, M.Y., Khan, S.Y. and Ahmad, N. 2006. Performance characteristics of compression ignition engine when operated on preheated Neem oil. Proceeding of International Conference on Advances in Mechanical Engineering, Punjab, Dec 1-3.

Kumar Reddy, V.K. 2000. Experimental investigations on the use of vegetable oil fuels in a 4-stroke single cylinder diesel engine. Ph.D Thesis, submitted at JNTU, Anantapur.

Lin, C.Y. Chen, L.W. and Wang, L.W. 2006. Correlation of black smoke and nitrogen oxides emissions through field testing of in-use diesel vehicles. Environmental Monitoring and Assessment, 116(1-3): 291-305.

Naik, M., Meher, L.C., Naik, S.N. and Das, L.M. 2008. Production of biodiesel from high free fatty acid Karanja (Pongamia pinnata) oil. Biomass and Bioenergy, 32: 354-357.

Narayan, C.M. 2002. Vegetable oil as engine fuels - prospect and retrospect. Proceedings on Recent Trends in Automotive Fuels, Nagpur, India.

Radha, K.K. 2008. Experimental investigations on 4 stroke C.I. engine using non-edible vegetable oils as alternate fuels, Ph.D. Thesis, JNTU, Hyderabad.

Radwan M.S., Ismail, M.A., Elfeky, S.M.S. and Abu- Elyazeed, O.S.M. 2007. Jojoba methyl ester as a diesel fuel substitute: Preparation and characterization. Applied Thermal Engineering, 27: 314-322.

Ramadhas, A.S., Jayaraj, S. and Lakshmi Narayana Rao, K. 2002. Experimental investigation on non-edible vegetable oil operation in diesel engine for improved performance. National Conference on Advances in Mechanical Engineering, JNTU., Anantapur, India.

Ravi Kumar, P., Dutta, M., Puli, R.K. and Babu, V. 2007. Performance of I.C Engine using vegetable oil. Proceeding of International Conference and XX National Conference on IC Engines and Combustion, ICONICE-2007, JNTU, Hyderabad. 
Srinivasa Murthy, V.S. 2005. Investigations on the use of vegetable oil in a low heat rejection CI engine. Ph.D. Thesis, JNTU, Anantapur, India.

\section{Nomenclature}

bTDC

before top dead centre

BTE

brake thermal efficiency

BSFC

$\mathrm{CO}$

brake-specific fuel consumption $(\mathrm{kg} / \mathrm{kWh})$

$\mathrm{CO}_{2}$

DO

carbon monoxide

$\mathrm{HC}$

carbon dioxide

IP

diesel oil

IT

hydrocarbon (PPM)

injection pressure (bar)

JO injection timing $\left({ }^{\circ} \mathrm{CA}\right)$

JME

$\mathrm{NO}$

jojoba oil

$\mathrm{NO}_{\mathrm{x}}$ jojoba methyl ester

neem oil

TDC

oxides of nitrogen (PPM)

TO

top dead centre

thumba oil 